\title{
Performance and meat quality of Nellore bulls fed crude glycerin combined with soybean oil
}

\author{
G. Fiorentini $^{\mathrm{a}, *}$, J.D. Messana ${ }^{\mathrm{a}}$, A. José Neto ${ }^{\mathrm{a}}$, E.G. Sgobi ${ }^{\mathrm{a}}$, P.S. Castagnino ${ }^{\mathrm{a}}$, \\ T.T. Berchielli ${ }^{\mathrm{a}, \mathrm{b}}$

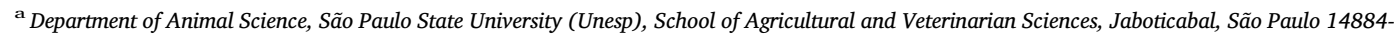 \\ 900, Brazil \\ ${ }^{\mathrm{b}}$ INCT/CA-UFV-Department of Animal Science, Av. Peter Henry Rolfs s/n, Campus Universitário, Viçosa, Minas Gerais CEP 36570-000, Brazil
}

\section{A R T I C L E I N F O}

\section{Keywords:}

Beef cattle

Fatty acid

Intake

Lipid profile

\begin{abstract}
A B S T R A C T
The objective of this experiment was to determine the effect of crude glycerin combined with soybean oil on the performance and fatty acid composition of the longissimus muscle in Nellore bulls. Twenty-eight Nellore young bulls, each with an initial body weight (BW) of $408 \pm 29 \mathrm{~kg}$ (age $20 \pm 2$ months), were used in a completely randomized design over a period of 84 days in a $2 \times 2$ factorial arrangement. The treatments were diets with crude glycerin at $100 \mathrm{~g} / \mathrm{kg} \mathrm{DM}$ $(\mathrm{CG}+$ ) or without crude glycerin (CG -); diet with inclusion of soybean oil at $60 \mathrm{~g} / \mathrm{kg}$ DM (Oil +) or without soybean oil inclusion (Oil-). All diets were composed of corn silage $(400 \mathrm{~g} / \mathrm{kg} \mathrm{DM}$ ), used as the only source of roughage, and concentrate $(600 \mathrm{~g} / \mathrm{kg} \mathrm{DM})$. The intake of the dry matter ( $\mathrm{g} / \mathrm{kg}$ of body weight), neutral detergent fiber (aNDF) and crude protein decreased with soybean oil inclusion, independent of crude glycerin addition. The aNDF digestibility decreased in diets with soybean oil and without crude glycerin. The DM and organic matter (OM) were most digestible in diets that added crude glycerin but excluded soybean oil. Animals fed soybean oil without crude glycerin exhibited higher intake of linoleic acids, total unsaturated fatty acids (UFA), and total polyunsaturated fatty acids (PUFA) than those fed other diets. There were no effects of oil or crude glycerin feeding on final body weight, average daily gain (ADG), hot carcass weight, subcutaneous fat thickness, or loin eye area $(P>0.05)$. Animals fed soybean oil incorporate into the muscle $40 \%$ more conjugated linoleic acids (CLA) and 32\% more linoleic acids compared to other diets. The addition of crude glycerin decreased the elongase index $(P=0.04)$ in the longissimus muscle. The combination of crude glycerin and soybean oil did not effectively increase performance or unsaturated fatty acid deposition in meat. However, the addition of soybean oil at $60 \mathrm{~g} / \mathrm{kg}$ DM optimized feed efficiency and did not alter ADG.
\end{abstract}

\footnotetext{
Abbreviations: ADG, average daily weight gain; aNDF, neutral detergent fiber assayed with a heat stable amylase and expressed inclusive of residual ash; BW, body weight; CCW, cold carcass weight; CKL, cook loss; CLA, conjugated linoleic acids; CG, crude glycerin; DM, dry matter; DMI, dry matter intake; FA, fatty acid; GE, gross energy; iNDF, indigestible neutral detergent fiber; LEA, longissimus loin-eye area; MFI, myofibril fragmentation indices; MUFA, monounsaturated fatty acids; n-3, fatty acids of the omega- 3 series; $n-6$, fatty acids of the omega- 6 series; OM, organic matter; pHu, ultimate carcass pH; PUFA, total polyunsaturated fatty acids; SFA, total saturated fatty acids; SFT, subcutaneous fat thickness; TBARS, thiobarbituric acid-reactive substances; UFA, total unsaturated fatty acids; WBSF, warner-bratzler shearforce; WHC, water holding capacity

* Corresponding author at: Departamento de Zootecnia, Faculdade de Ciências Agrárias e Veterinárias de Jaboticabal, Universidade Estadual Paulista "Júlio de Mesquita Filho," Rod. Professor Paulo Donato Castellane, km 5, Rural, Jaboticabal, São Paulo CEP: 14884-900, Brazil.

E-mail address: fiorentini.giovani@gmail.com (G. Fiorentini).
} 


\section{Introduction}

A variety of feed types has been used in diets of beef cattle to meet energy needs and to maintain or reduce ingredient costs (Hales et al., 2013). Crude glycerin, a biodiesel by-product, can replace cereal grain (e.g., corn) without affecting performance of beef cattle in feedlot diets (Mach et al., 2009; Lage et al., 2014).

Lipids have also been utilized to increase the energy density of high-producing dairy cow diets and to improve meat quality in finishing beef cattle (Fiorentini et al., 2015; Bayat et al., 2018). However, higher levels of fat in ruminant diets have also been known to compromise rumen fermentation, fiber utilization and intake, and animal production (Eugène et al., 2011). According to Sullivan et al. (2004), diets containing more than $70 \mathrm{~g} / \mathrm{kg}$ EE in the DM can impair feed degradation, especially if there is a high proportion of unsaturated fatty acid (UFA) than saturated fatty acids (SFA; Harfoot and Hazlewood, 1997) depending on the structural characteristics of the lipid source added to the basal diet (Jenkins and Mcguire, 2006). That happens due to many factors, such as fiber coating, toxic effect to Gram-positive bacteria and protozoa, and modifying hydrogen uptake by methanogens (Goel et al., 2009). However, some studies in vitro (Krueger et al., 2010; Edwards et al., 2012) and in vivo (Granja-Salcedo et al., 2017) demonstrated inhibition of ruminal lipase activity when glycerol was combined with oils, and possible increases in the flow of UFA to the intestine without detrimental effects on fermentation.

Thus, if UFA arrives intact in the gut, the meat may be richer in UFA (i.e. $\alpha$-linolenic, and linoleic), providing beneficial health properties. But, despite the fact that the ruminant diet is rich in polyunsaturated fatty acids (PUFA), ruminant products - meat, milk and dairy - contain mainly SFA because of bacterial lipolysis and subsequent biohydrogenation of ingested PUFA in the rumen (Lourenco et al., 2010). The consumption of saturated fats, of which beef is richer than other sources have been reported to increase the risk of cardiovascular disease in humans (Briggs et al., 2017).

In this context, we find necessary to investigate the effects of the combination of crude glycerin with oils on performance and meat traits of beef, since, to our knowledge, no previous studies have addressed this question. Here, we describe an experiment evaluating the effect of crude glycerin $(100 \mathrm{~g} / \mathrm{kg} \mathrm{DM})$ combined with soybean oil $(60 \mathrm{~g} / \mathrm{kg} \mathrm{DM})$ on intake, nutrient digestibility, average daily gain, meat traits, and fatty acid composition of the longissimus muscle.

\section{Materials and methods}

The procedures carried out in this experiment were approved by the Ethics, Bioethics, and Animal Welfare Committee (Comissão de Ética and Bem Estar Animal) of the Faculty of Agriculture and Veterinary Sciences - São Paulo State University (UNESP) protocol no. 021119/11. The experiment was conducted in the feedlot facilities at the Digestibility Unit of the Department of Animal Science at the School of Agricultural and Veterinarian Sciences, Jaboticabal, Brazil.

\subsection{Animals and experimental design}

Twenty-eight Nellore young bulls (initial body weight $[\mathrm{BW}]=408 \pm 29 \mathrm{~kg} ; 20 \pm 2$ months) were housed in individual $12 \mathrm{~m}^{2}$ ( 4 by $3 \mathrm{~m}$ ) pens that were provided with a concrete trough and drinker. Animals underwent 21 days of adaptation to the experimental installations and diets and a period of 84 days to evaluate performance and meat traits. In the adaptation period, all the animals were weighed after $16 \mathrm{~h}$ of fasting and before the first feeding in the morning. The average daily gain (ADG) was obtained by weighing animals at the beginning and at the end of the experiment (84 days), always after a 16-h solid fast.

\subsection{Diets, sampling, and data collection}

The animals were manually fed two times daily at $0700 \mathrm{~h}$ and $1400 \mathrm{~h}$. The diets were formulated to be isonitrogenous and to provide a dry matter intake of $23 \mathrm{~g} / \mathrm{kg}$ of body weight and an average gain of $1.5 \mathrm{~kg} /$ day (Valadares Filho et al., 2010). Amounts of feed offered to animals were calculated according to previous dry matter intake (DMI) and adjustments were made when needed so that refused feed did not exceed $100 \mathrm{~g} / \mathrm{kg}$ of daily intake.

The treatments were diets with crude glycerin at $100 \mathrm{~g} / \mathrm{kg}$ DM $(\mathrm{CG}+)$ or without crude glycerin (CG - ); diet with inclusion of soybean oil at $60 \mathrm{~g} / \mathrm{kg} \mathrm{DM}(\mathrm{Oil}+)$ or without soybean oil inclusion (Oil-). All diets were composed of corn silage (400 g/kg DM), used as the only source of roughage, and concentrate $(600 \mathrm{~g} / \mathrm{kg} \mathrm{DM}$; Table 1$)$. The crude glycerin was obtained from biodiesel production based on soybean oil (glycerin: $803.4 \mathrm{~g} / \mathrm{kg}$; ether extract: $15.9 \mathrm{~g} / \mathrm{kg}$; ash: $50.3 \mathrm{~g} / \mathrm{kg}$; water: $120.2 \mathrm{~g} / \mathrm{kg}$ ). Owing to the inclusion of oil and glycerin, concentrates were prepared to be consumed within a maximum of $4 \mathrm{~d}$, in order to prevent the oxidation of dietary ingredients.

Daily leftovers were collected and weighed daily before the morning feeding of animals. At the end of each experimental period, composite samples were collected for each animal based on the leftovers' weight, and stored at $-20^{\circ} \mathrm{C}$. Feed samples were frozen at $-20^{\circ} \mathrm{C}$ for later analysis. Samples were dried at $55^{\circ} \mathrm{C}$ for $72 \mathrm{~h}$ and ground in a Wiley mill (Thomas Scientific, Swedesboro, NJ, USA) to pass through a $1 \mathrm{~mm}$ screen and analyzed to determine DM (method 934.01) and mineral matter (MM; method 942.05) and to obtain an ether extract (EE; method 954.02) according to AOAC (1990). Nitrogen content was determined using an LECO FP-528 nitrogen analyzer (LECO Corp., St. Joseph, MI, USA). Neutral detergent fiber (aNDF) content was determined using $\alpha$-amylase and without the addition of sodium sulfite following Van Soest et al. (1991) and adapted for the Ankom ${ }^{200}$ Fiber Analyzer (Ankom Technology, Fairport, NY). The gross energy (GE) content of feeds and refusals was determined using an adiabatic bomb calorimeter (PARR Instrument Company 6300, Moline, IL, USA). 
Table 1

Ingredient proportion, chemical composition, and principal fatty acids of experimental diets.

\begin{tabular}{|c|c|c|c|c|}
\hline & \multicolumn{2}{|c|}{ Treatments $^{\mathrm{a}}$} & & \\
\hline & \multicolumn{2}{|l|}{ CG +} & \multicolumn{2}{|l|}{ CG- } \\
\hline & Oil + & Oil- & Oil + & Oil- - \\
\hline Corn silage & 400 & 400 & 400 & 400 \\
\hline Corn & 258 & 332 & 380 & 455 \\
\hline Soybean meal & 157 & 143 & 135 & 120 \\
\hline Crude glycerin & 100 & 100 & 0.00 & 0.00 \\
\hline Urea & 10.0 & 10.0 & 10.0 & 10.0 \\
\hline Soybean oil & 60.0 & 0.00 & 60.0 & 0.00 \\
\hline Commercial premix ${ }^{\mathrm{b}}$ & 15.0 & 15.0 & 15.0 & 15.0 \\
\hline Dry matter & 643 & 638 & 645 & 639 \\
\hline Crude protein & 166 & 166 & 167 & 166 \\
\hline Neutral Detergent Fiber & 300 & 286 & 285 & 289 \\
\hline Ether extract & 877 & 309 & 872 & 305 \\
\hline Gross energy, $\mathrm{Mcal} / \mathrm{kg} D M$ & 485 & 458 & 488 & 452 \\
\hline Myristic & 0.45 & 0.63 & 0.30 & 0.28 \\
\hline Palmitic & 17.3 & 18.6 & 21.2 & 26.1 \\
\hline Palmitoleic & 0.56 & 0.86 & 0.77 & 0.60 \\
\hline Stearic & 3.80 & 5.84 & 4.10 & 4.63 \\
\hline Oleic & 38.4 & 37.1 & 38.9 & 40.1 \\
\hline Linoleic & 37.5 & 29.4 & 33.5 & 24.7 \\
\hline$\alpha$-linolenic & 1.14 & 1.57 & 1.15 & 0.37 \\
\hline SFA & 21.8 & 28.1 & 25.3 & 32.9 \\
\hline UFA & 78.2 & 71.9 & 74.7 & 67.1 \\
\hline MUFA & 39.5 & 38.9 & 40.0 & 41.0 \\
\hline PUFA & 38.7 & 32.9 & 34.7 & 26.1 \\
\hline
\end{tabular}

${ }^{\text {a }}$ Diet with CG at $100 \mathrm{~g} / \mathrm{kg}$ DM (CG +) or without crude glycerin (CG-); diet with inclusion of soybean oil at $60 \mathrm{~g} / \mathrm{kg} \mathrm{DM} \mathrm{(Oil+)} \mathrm{or} \mathrm{without}$ soybean oil inclusion (Oil-).

b $120 \mathrm{~g}$ calcium, $30 \mathrm{~g}$ phosphorus, $25 \mathrm{~g}$ sulfur, $80 \mathrm{~g}$ sodium, $330 \mathrm{mg}$ copper, $950 \mathrm{mg}$ manganese, $1220 \mathrm{mg}$ zinc, $24 \mathrm{mg}$ iodine, $20 \mathrm{mg}$ cobalt, $6 \mathrm{mg}$ selenium, and $300 \mathrm{mg}$ fluorine; SFA = saturated fatty acids; UFA = unsaturated fatty acids; MUFA = monounsaturated fatty acids; PUFA $=$ polyunsaturated fatty acids.

Total fatty acids (FA) were extracted from the feed ingredients, and leftovers samples by means of the methylation method described by Palmquist and Jenkins (2003). The fatty acids were methylated with $5 \mathrm{~m} \mathrm{~L} \mathrm{of} 10 \%$ methanolic $\mathrm{HCl}\left(2 \mathrm{~h}\right.$ at $\left.90{ }^{\circ} \mathrm{C}\right) . \mathrm{During}$ this process, $1 \mathrm{~mL}$ of nonadecanoic acid C19:0 at 2.0\% was added to each sample, which was used as the internal standard for FA quantification. The FA profile was quantified by gas chromatography(GC Shimatzu model 20-10, with automatic injection; Shimatzu Corporation, Kyoto, Japan) using a SP-2560 capillary column $(100 \mathrm{~m} \times 0.25 \mathrm{~mm}$ diameter, $0.02 \mathrm{~mm}$ thick; Supelco, Bellefonte, PA, USA), and hexane as carrier gas. In order to identify each FA, we used external standards (Supelco, Bellefonte, PA, USA; Nu-Chek Prep, Elysian, MN, USA), whereas an internal standard (C19:0) was used for quantification.

Digestibility trials were performed at the end of the each experimental period (26, 27, and 28 days), with daily collection of feces at upper layer from each animal collected from the floor of the stalls immediately after defecation, for three consecutive days at the hours of 0700,1100 , and 1600 on the first, second, and third days of collection, respectively (Ferreira et al., 2009). After being identified, feces were pre-dried in a forced-air oven at $55{ }^{\circ} \mathrm{C}$ for approximately $72 \mathrm{~h}$ and ground through a 1 -mm sieve mill. A composite sample based on the air-dry weight was made from the three samples of ground feces. The fecal output of dry matter was estimated by the internal marker technique (Cochran et al., 1986), using the indigestible neutral detergent fiber (iNDF) marker. The iNDF was obtained by the in situ method for $288 \mathrm{~h}$ (Valente et al., 2011) with subsequent extraction of the neutral detergent fiber, according to methods described by Van Soest et al. (1991).

At the end of the trial period (105 d), the animals (average BW of $526 \pm 36 \mathrm{~kg}$ ) fasted for $16 \mathrm{~h}$ on the day prior to transportation to the slaughterhouse. After slaughter, carcasses were transferred to a cooler at $4{ }^{\circ} \mathrm{C}$ and chilled for $24 \mathrm{~h}$. After the postmortem chill period, the cold carcass weight (CCW), ultimate carcass $\mathrm{pH}$ (pHu), 12th rib subcutaneous fat thickness (SFT) and 12th rib longissimus loin-eye area (LEA) were measured on the left side of each carcass. The LEAs were traced on transparencies and measured later with a planimeter and SFT measurements were taken at 3/4 of the ventral length over the longissimus muscle (Greiner et al., 2003). Each chilled longissimus sample was standardized from the cranial end of the loin break to form one 2.54-cm thick steak sample (AMSA, 1995) for further analysis. All steaks were vacuum-packed ( $99 \%$ vacuum, with a 200 Selovac Sealer machine [Selovac, São Paulo, SP, Brazil]) in polyamide/polyethylene pouches of $120 \mu \mathrm{m}$ and $1 \mathrm{~cm}^{3} / \mathrm{m}^{2} / 24 \mathrm{~h} \mathrm{O}$ permeability, $3 \mathrm{~cm}^{3} / \mathrm{m}^{2} / 24 \mathrm{~h} \mathrm{CO}$ permeability measured at $5{ }^{\circ} \mathrm{C}$, and $75 \%$ relative humidity; water vapor transmission rate was $3 \mathrm{~g} / \mathrm{m}^{2} / 24 \mathrm{~h}$ at $38{ }^{\circ} \mathrm{C}$ and $100 \% \mathrm{RH}$. Vacuum value $20(50 \mathrm{~Pa})$ was used to pack the steaks and samples held at $-20^{\circ} \mathrm{C}$ for 10 days until analysis. 


\subsection{Proximate analysis}

After thawing at room temperature, the meat samples were lyophilized for $36 \mathrm{~h}$ to obtain homogeneous and moisture-free samples, ground in a Wiley mill (Thomas Scientific, Swedesboro, NJ), and passed through a 1-mm screen. The chemical composition was determined according to the methods of the Association of Official Analytical Chemists (AOAC, 1990). Crude protein was quantified by the Kjeldahl method, EE was extracted by the Soxhlet method, and the ashes were obtained through a muffle furnace at $550{ }^{\circ} \mathrm{C}$.

\subsection{Meat color and water holding capacity (WHC)}

The L* (lightness), a* (redness), and b* (yellowness) color components were determined during blooming following removal of the filets from the packaging, and exposure to air for $30 \mathrm{~min}$ to permit the oxygenation of myoglobin (Tapp III et al., 2011). The color reading was performed on the surface of the steaks using the CIE L*a*b* system, illuminant D65 and at a standard observation angle of $10^{\circ}$. A Minolta CR-400 colorimeter (Konica Minolta, Osaka, Japan) was used and three readings per slice were performed, and the averages were used in the statistical analyses. The colorimeter was calibrated before analyzing the samples against white and black standards. After evaluating the color of each steak, approximately $2 \mathrm{~g}$ were collected to determine the WHC. This value was the difference between the weights of the sample before and after it was subjected to 10-kg pressure for $5 \mathrm{~min}$.

\subsection{Myofibril fragmentation index}

Myofibril fragmentation indices (MFI) were determined on fresh muscle according to the procedures described by Olson et al. (1976) and modified by Culler et al. (1978). Minced muscle (4 g) was homogenized for $30 \mathrm{~s}$ in 10 volumes (v/w) of a $2{ }^{\circ} \mathrm{C}$ isolating medium consisting of $100 \mathrm{mM} \mathrm{KCl}, 20 \mathrm{mM} \mathrm{KPO}_{4}, 1 \mathrm{mM}$ EDTA, $1 \mathrm{mM} \mathrm{MgCl} 2$, and $1 \mathrm{mM}$ sodium azide. The homogenate was centrifuged at $1000 \times g$ for $15 \mathrm{~min}$ and the supernatant was decanted. The sediment was then suspended in 10 volumes (v/w) of isolating medium using a stir rod, centrifuged again at $1000 \times g$ for $15 \mathrm{~min}$. and the supernatant was decanted. The sediment was suspended in 2.5 volumes $(\mathrm{v} / \mathrm{w})$ of isolating medium and passed through a polyethylene strainer $(18 \mathrm{mesh})$ to remove connective tissue and debris. An additional 2.5 volumes $(\mathrm{v} / \mathrm{w})$ were used to facilitate the passage of myofibrils through the strainer. The protein concentration of the myofibril suspension was determined by the biuret method as described by Gornall et al. (1949). An aliquot of the myofibril suspension was diluted with an isolating medium to obtain a protein concentration of $0.5 \pm 0.05 \mathrm{mg} / \mathrm{mL}$. Protein concentration was determined by the biuret method. The diluted myofibril suspension was stirred and poured into a cuvette; absorbance of this suspension was immediately measured at $540 \mathrm{~nm}$. Absorbance was multiplied by 200 to obtain an MFI for each sample.

\subsection{Warner-Bratzler shear-force (WBSF) measurement and cook loss (CKL)}

The Warner-Bratzler shear-force (WBSF) steaks were thawed at $4{ }^{\circ} \mathrm{C}$ for $24 \mathrm{~h}$ and oven-broiled in an electric oven (Layr, Luxo Inox) preheated to $150{ }^{\circ} \mathrm{C}$. Internal steak temperatures were monitored by 20-gauge copper-constantan thermocouples (Omega Engineering, Stamford, CT, USA) placed in the approximate geometric center of each steak and attached to a digital monitor. When the internal temperature reached $35^{\circ} \mathrm{C}$, the steak was turned and allowed to reach an internal temperature of $70{ }^{\circ} \mathrm{C}$ before being removing from the oven. Cooked WBSF steaks were cooled for $24 \mathrm{~h}$ at $4{ }^{\circ} \mathrm{C}$ (AMSA, 1995). Five round cores (1.27-cm diameter) were removed from each steak parallel to the long axis of the muscle fibers (AMSA, 1995). Each core was sheared once through the center, perpendicular to the fiber direction using a Warner-Bratzler shear machine (G-R Manufacturing Company, Manhattan, KS, USA). Cook loss was evaluated on the steaks that were also used to measure WBSF. Total cook loss (CKL) was calculated as the difference between the weight of the steaks before and after oven broiling, thawing loss (TL) was calculated as the difference between the weight of the steaks before and after thawing, and total loss was calculated by adding the time for CKL and TL.

\subsection{Thiobarbituric acid-reactive substances (TBARS)}

The presence of thiobarbituric acid-reactive substances (TBARS) was determined according to the method described by Tarladgis et al. (1960). Meat samples ( $50 \mathrm{~g}$ ) were identified and vacuum packed in polyethylene bags and incubated for 0,7 , and 14 days at $1{ }^{\circ} \mathrm{C}$ in a Bio-Chemical Oxygen Demand incubator. A 10-g meat sample was first ground in a multiprocessor, and $0.2 \mathrm{~mL}$ of butylated hydroxytoluene antioxidant (0.03\%), $50 \mathrm{~mL}$ of distilled water, and $1 \mathrm{~mL}$ of an antifoaming solution were added (Sigma A5758, São Paulo, Brazil). The samples were ground and homogenized for $1 \mathrm{~min}$. After homogenization, the samples were transferred to a 250mL flask containing porcelain pieces, and $50 \mathrm{~mL}$ of a $4 \mathrm{M} \mathrm{HCl}$ solution was added. Subsequently, the samples were distilled in a blanket heater at $100{ }^{\circ} \mathrm{C}$ until $50 \mathrm{~mL}$ of the distillate was collected. Five milliliters of the distillate were transferred to a test tube, and $5 \mathrm{~mL}$ of $0.02 \mathrm{M}$ TBA solution was then added. The test tubes were incubated in a boiling water bath for $35 \mathrm{~min}$, and the absorbance was measured at $530 \mathrm{~nm}$ in a spectrophotometer (Hitachi High Technologies America, Inc., model U-2,900, Pleasanton, CA, USA). The TBARS value, expressed in milligrams of MDA per kilogram of meat, was obtained using a conversion factor based on a standard curve using 1, 1, 3, 3-tetraethoxypropane. 


\subsection{Fatty acid composition}

The fatty acid composition was determined in samples of the transverse section collected from the longissimus muscle. After collection, the samples were freeze-dried for lipid extraction and methylation. About $100 \mathrm{~g}$ of triturated sample was weighed, then $100 \mathrm{~mL}$ of chloroform and $200 \mathrm{~mL}$ of methanol were added and homogenized in a Waring Blendor for 2 min (Bligh and Dyer, 1959) and the fatty acid methyl esters (FAME) were obtained by the ISO 5509 method (1978). The methyl esters from FAMES were formed using a $\mathrm{KOH}$ solution in methanol. Qualitative and quantitative measurements of fatty acid content were performed by gas chromatography (Shimadzu, Kyoto, Japan-Model GC-14B with a Communication Bus Module-CBM 102) with a flame ionization detector and fused silica capillary column (Omegawax 250), which was $100 \mathrm{~m}$ in length and $0.25 \mathrm{~mm}$ in diameter and had a film thickness of $0.25 \mu \mathrm{m}$ (Supelco SP-24136). Helium was used as a carrier gas at a flow rate of $1 \mathrm{~mL} / \mathrm{min}$. A $1-\mu \mathrm{L}$ aliquot of the sample was injected into a "split" at a division ratio of $1 / 100$ and a temperature of $250{ }^{\circ} \mathrm{C}$. The oven temperature was maintained at $100{ }^{\circ} \mathrm{C}$ for $2 \mathrm{~min}$ and then increased to $220^{\circ} \mathrm{C}$ at $4{ }^{\circ} \mathrm{C} / \mathrm{min}$ for $25 \mathrm{~min}$, whereas the detector was at $280^{\circ} \mathrm{C}$. Methyl esters of the fatty acids were identified and quantified by comparing with the retention times and concentrations of methyl esters of standard fatty acids.

Activity indices were calculated for elongase and $\Delta^{9}$-desaturase on fatty acids containing 16 and 18 carbon atoms. These enzymes are responsible for the conversion of SFAs with 16 and 18 carbon atoms into their respective monounsaturated components, with double bonds at carbon 9 as described by Malau-Aduli et al. (1997). The atherogenicity index was calculated as described by Ulbricht and Southgate (1991) as an indicator of risk of cardiovascular disease. Calculations were performed as it follows:

$$
\begin{aligned}
& \Delta^{9} \text {-desaturase activity 16: } 100[(\mathrm{C} 16: 1 \text { cis9)/(C16:1 cis9 + C16:0)]; } \\
& \Delta^{9} \text {-desaturase activity 18: 100[(C18:1 cis9)/(C18:1 cis9 + C18:0)]; } \\
& \text { Elongase activity: } 100[(\mathrm{C} 18: 0+\mathrm{C} 18: 1 \text { cis9)/(C16:0 + C16:1cis9 + C18:0 + C18:1cis9)]; and }
\end{aligned}
$$$$
\text { Atherogenic index: }[\mathrm{C} 12: 0+4(\mathrm{C} 14: 0)+\mathrm{C} 16: 0] / \Sigma \mathrm{SFA}+\Sigma \mathrm{PUFA})
$$

\subsection{Statistical analysis}

The data of animal performance and carcass traits were evaluated in a completely randomized design arranged in a $2 \times 2$ factorial design of crude glycerin and soybean oil. Data were analyzed using the PROC MIXED procedure of SAS software (version 9.4; SAS Institute Inc., Cary, NC, USA). Statistical model included the fixed effect of soybean oil ( $1^{\circ}$ of freedom, DF), crude glycerin (1 DF) and all interactions. Initial BW was included as a covariate in the analysis for all variables. Homogeneity of the data was verified using the UNIVARIATE procedure of SAS. Studentized residuals were plotted against the predicted values using the plot procedure to analyze data for outliers. Results were subjected to analysis of variance with means compared by Tukey's test at a significance level of 0.05 .

\section{Results}

Intake of DM ( $\mathrm{g} / \mathrm{kg}$ of body weight), aNDF, and crude protein decreased with the inclusion of soybean oil $(P<0.01$; Table 2$)$. The inclusion of both crude glycerin and soybean oil decreased the intake of DM and OM $(P<0.01)$. The intake of EE was greater in diets with soybean oil $(P<0.01)$. The aNDF digestibility decreased in diets with soybean oil and without crude glycerin $(P<0.01)$. There was an interaction between crude glycerin and soybean oil for digestibility of DM, OM, and EE $(\mathrm{P}<0.01)$. The addition of crude glycerin combined in diets without soybean oil resulted in higher digestibility of the DM and OM compared with all diets $(P<0.01)$ and increased digestibility in diets with crude glycerin, independent of soybean oil inclusion. Animals fed crude glycerin without oil inclusion had greater digestibility than those fed without crude glycerin and soybean oil ( $<<0.01$; Table 2$)$.

There was an effect of crude glycerin and soybean oil consumed together on the intake of stearic acids, linoleic acids, total UFA, and total polyunsaturated fatty acid (PUFA, $P<0.01$; Table 2). Animals fed crude glycerin and soybean oil had greater intake of stearic acid than those consuming other diets. Animals fed soybean oil without crude glycerin had a higher intake of linoleic acid, total UFA, and total PUFA than those fed other diets. The intake of oleic acid and total monounsaturated fatty acids (MUFA) was greater in soybean oil diets $(P<0.01)$. The intake of lauric, myristic, pentadecanoic, and palmitoleic acids and of total SFA increased in diets with soybean oil and no crude glycerin $(P<0.01)$.

There were no effect of oil or crude glycerin on final body weight, average daily gain, hot carcass weight, subcutaneous fat thickness, loin eye area $(P>0.05$; Table 3$)$, or the chemical composition of meat $(P>0.05$; Table 4$)$. There was an interaction between oil and crude glycerin for hot carcass yield $(P=0.02)$. Diets with both soybean oil and crude glycerin decreased the hot carcass yield compared to diets with crude glycerin and no soybean oil, and then diets with neither crude glycerin nor soybean oil $(P=0.02)$. The addition of soybean oil increased feed efficiency by $15 \%$, independent of crude glycerin addition $(P<0.01$; Table 3). There was no effect of crude glycerin or soybean oil on $\mathrm{pH}$, color ( $\mathrm{L}^{*}, \mathrm{a}^{*}$ and $\mathrm{b*}$ ), water holding capacity, myofibrillar fragmentation index, Warner-Bratzler shear force, malonaldehyde, thawing loss, cooking loss, and total loss $(P>0.05$; Table 5).

The inclusion of soybean oil decreased the amount of myristic, myristoleic, palmitoleic, and oleic acids in the meat $(P<0.05$; Table 6). The vaccenic acid content in the meat increased by $12 \%$ in the longissimus muscle in diets containing soybean oil. The interaction between crude glycerin and soybean oil had an effect on the concentration of pentadenoic acid in meat $(P=0.01)$. The pentadenoic acid in meat was greater in diets with crude glycerin combined with oil and diets without crude glycerin and without 
Table 2

Effects of crude glycerin and soybean oil on intake and digestibility of Nellore bulls in feedlot.

\begin{tabular}{|c|c|c|c|c|c|c|c|c|}
\hline & \multicolumn{4}{|c|}{ Treatments $^{1}$} & \multirow[t]{3}{*}{ SEM } & \multicolumn{3}{|l|}{ P-value } \\
\hline & \multicolumn{2}{|l|}{$\mathrm{CG}+$} & \multicolumn{2}{|l|}{ CG- } & & \multirow[b]{2}{*}{ CG } & \multirow[b]{2}{*}{ Oil } & \multirow[b]{2}{*}{$\mathrm{CG} \times$ Oil } \\
\hline & Oil+ & Oil- & Oil + & Oil- & & & & \\
\hline $\begin{array}{l}\text { Number of observations } \\
\text { Intake, } \mathrm{g} / \mathrm{kg} \text { of body weight }\end{array}$ & 7 & 7 & 7 & 7 & & - & - & - \\
\hline Dry matter & 1.91 & 2.10 & 1.85 & 2.08 & 0.042 & 0.39 & $<0.01$ & 0.71 \\
\hline \multicolumn{9}{|l|}{ Intake, $\mathrm{kg} / \mathrm{d}$} \\
\hline Dry matter & 8.45 & 9.72 & 8.87 & 10.3 & 0.23 & 0.04 & $<0.01$ & 0.73 \\
\hline Organic matter & 7.95 & 9.15 & 8.43 & 9.79 & 0.22 & 0.02 & $<0.01$ & 0.71 \\
\hline aNDF & 2.56 & 2.70 & 2.56 & 2.98 & 0.06 & 0.06 & $<0.01$ & 0.06 \\
\hline Crude Protein & 1.38 & 1.61 & 1.45 & 1.70 & 0.04 & 0.06 & $<0.01$ & 0.89 \\
\hline Ether extract & 0.75 & 0.29 & 0.76 & 0.30 & 0.01 & 0.47 & $<0.01$ & 0.88 \\
\hline \multicolumn{9}{|l|}{ Fatty acids intake, $\mathrm{g} / \mathrm{d}$} \\
\hline Lauric & 0.36 & 0.40 & 0.38 & 0.42 & 0.01 & 0.03 & $<0.01$ & 0.83 \\
\hline Myristic & 0.24 & 0.33 & 0.32 & 0.35 & 0.02 & 0.03 & $<0.01$ & 0.16 \\
\hline Pentadecanoic & 0.42 & 0.47 & 0.45 & 0.50 & 0.01 & 0.04 & $<0.01$ & 0.89 \\
\hline Palmitic & 143 & 56.7 & 168 & 79.4 & 3.47 & $<0.01$ & $<0.01$ & 0.80 \\
\hline Stearic & $44.0^{\mathrm{a}}$ & $11.2^{\mathrm{d}}$ & $29.7^{\mathrm{b}}$ & $13.5^{\mathrm{c}}$ & 0.65 & $<0.01$ & $<0.01$ & $<0.01$ \\
\hline Palmitoleic & 0.26 & 0.29 & 0.28 & 0.31 & 0.01 & 0.03 & $<0.01$ & 0.72 \\
\hline Oleic & 279 & 110 & 297 & 111 & 4.75 & 0.06 & $<0.01$ & 0.08 \\
\hline Linoleic & $211^{\mathrm{b}}$ & $124^{\mathrm{c}}$ & $245^{\mathrm{a}}$ & $88.3^{\mathrm{d}}$ & 6.54 & 0.92 & $<0.01$ & $<0.01$ \\
\hline$\alpha$-linolenic & 16.8 & 11.5 & 14.1 & 9.97 & 0.45 & $<0.01$ & $<0.01$ & 0.22 \\
\hline Total SFA & $192^{\mathrm{b}}$ & $69.1^{\mathrm{d}}$ & $203^{\mathrm{a}}$ & $94.2^{\mathrm{c}}$ & 3.17 & $<0.01$ & $<0.01$ & 0.03 \\
\hline Total UFA & $512^{\mathrm{b}}$ & $249^{c}$ & $558^{\mathrm{a}}$ & $211^{\mathrm{c}}$ & 13.6 & 0.76 & $<0.01$ & $<0.01$ \\
\hline Total MUFA & 292 & 113 & 304 & 113 & 5.29 & 0.23 & $<0.01$ & 0.24 \\
\hline Total PUFA & $228^{\mathrm{b}}$ & $136^{\mathrm{c}}$ & $260^{\mathrm{a}}$ & $98.3^{\mathrm{d}}$ & 6.96 & 0.70 & $<0.01$ & $<0.01$ \\
\hline \multicolumn{9}{|l|}{ Digestibility, $\mathrm{g} / \mathrm{kg} D M$} \\
\hline Dry matter & $694^{c}$ & $772^{\mathrm{a}}$ & $699^{c}$ & $737^{\mathrm{b}}$ & 2.91 & 0.02 & $<0.01$ & $<0.01$ \\
\hline Organic matter & $700^{c}$ & $778^{\mathrm{a}}$ & $706^{c}$ & $743^{\mathrm{b}}$ & 3.22 & 0.04 & $<0.01$ & $<0.01$ \\
\hline aNDF & 429 & 564 & 404 & 518 & 2.34 & $<0.01$ & $<0.01$ & 0.37 \\
\hline Ether extract & $885^{\mathrm{a}}$ & $789^{\mathrm{b}}$ & $887^{\mathrm{a}}$ & $742^{\mathrm{c}}$ & 4.67 & 0.02 & $<0.01$ & 0.01 \\
\hline
\end{tabular}

Adjusted averages to initial body weight as a covariate.

${ }^{1}$ Diet with CG at $100 \mathrm{~g} / \mathrm{kg}$ DM (CG +) or without crude glycerin (CG-); diet with inclusion of soybean oil at $60 \mathrm{~g} / \mathrm{kg} \mathrm{DM}(\mathrm{Oil}+)$ or without soybean oil inclusion (Oil-); SFAs = saturated fatty acids; UFAs = unsaturated fatty acids; MUFAs = monounsaturated fatty acids; PUFAs $=$ polyunsaturated fatty acids; ${ }^{\mathrm{a}-\mathrm{c}}$ Means within a row with different superscripts differ by Tukey's test at $\alpha=0.05$.

Table 3

Effects of crude glycerin and soybean oil on final body weight, average daily weight gain, feed efficiency, hot carcass weight (HCW), hot carcass yield, subcutaneous fat thickness, and loin eye area of Nellore bulls in feedlot.

\begin{tabular}{|c|c|c|c|c|c|c|c|c|}
\hline & \multicolumn{4}{|c|}{ Treatments $^{1}$} & \multirow[t]{3}{*}{ SEM } & \multicolumn{3}{|c|}{$P$-value } \\
\hline & \multicolumn{2}{|l|}{ CG + } & \multicolumn{2}{|l|}{ CG - } & & \multirow[b]{2}{*}{ CG } & \multirow[b]{2}{*}{ Oil } & \multirow[b]{2}{*}{$\mathrm{CG} \times$ Oil } \\
\hline & Oil + & Oil- & Oil + & Oil- & & & & \\
\hline Number of observations & 7 & 7 & 7 & 7 & - & - & - & - \\
\hline Final body weight, $\mathrm{kg}$ & 533 & 539 & 555 & 540 & 10.3 & 0.34 & 0.71 & 0.32 \\
\hline Average daily weight gain, $\mathrm{kg} / \mathrm{d}$ & 1.35 & 1.38 & 1.49 & 1.34 & 0.08 & 0.55 & 0.50 & 0.30 \\
\hline Feed efficiency, kg ADG/kg DMI & 0.158 & 0.141 & 0.168 & 0.135 & 0.01 & 0.80 & $<0.01$ & 0.35 \\
\hline Hot carcass weight, $\mathrm{kg}$ & 292 & 308 & 302 & 303 & 7.83 & 0.77 & 0.31 & 0.32 \\
\hline Hot carcass yield, $\mathrm{kg} / 100 \mathrm{~kg}$ of carcass & $54.6^{\mathrm{b}}$ & $57.1^{\mathrm{a}}$ & $55.8^{\mathrm{ab}}$ & $56.3^{\mathrm{a}}$ & 0.41 & 0.64 & $<0.01$ & 0.02 \\
\hline Subcutaneous fat thickness, mm & 6.13 & 6.20 & 7.29 & 6.15 & 0.85 & 0.53 & 0.54 & 0.49 \\
\hline Loin eye area, $\mathrm{cm}^{2}$ & 80.2 & 72.7 & 83.9 & 76.7 & 3.59 & 0.29 & 0.05 & 0.98 \\
\hline Loin eye area, $\mathrm{cm}^{2} / 100 \mathrm{~kg}$ HCW & 27.5 & 23.6 & 27.8 & 25.3 & 1.67 & 0.21 & 0.09 & 0.87 \\
\hline
\end{tabular}

${ }^{1}$ Diet with CG at $100 \mathrm{~g} / \mathrm{kg}$ DM (CG +) or without crude glycerin (CG-); diet with inclusion of soybean oil at $60 \mathrm{~g} / \mathrm{kg}$ DM (Oil +) or without soybean oil inclusion (Oil-); Adjusted averages to initial body weight as a covariate. ${ }^{\text {a-b }}$ Means within a row with different superscripts differ by Tukey's test at $\alpha=0.05$.

soybean oil than diets with soybean oil and without glycerol inclusion and diets with crude glycerin without soybean oil inclusion $(P<0.05)$.

Animals fed soybean oil exhibited greater presence of CLA (increase of 40\%) and linoleic acid (increase of 32\%) compared to 
Table 4

Effects of crude glycerin with or without soybean oil on chemical composition $(\mathrm{g} / \mathrm{kg})$ of meat from young Nellore bulls in feedlot.

\begin{tabular}{|c|c|c|c|c|c|c|c|c|}
\hline & \multicolumn{4}{|c|}{ Treatments $^{1}$} & \multirow[t]{3}{*}{ SEM } & \multicolumn{3}{|c|}{$P$-value } \\
\hline & \multicolumn{2}{|l|}{ CG + } & \multicolumn{2}{|l|}{ CG - } & & \multirow[b]{2}{*}{ CG } & \multirow[b]{2}{*}{ Oil } & \multirow[b]{2}{*}{$\mathrm{CG} \times \mathrm{Oi}$} \\
\hline & Oil + & Oil- & Oil + & Oil- & & & & \\
\hline Number of observations & 7 & 7 & 7 & 7 & - & - & - & - \\
\hline Moisture & 705 & 708 & 704 & 706 & 0.83 & 0.81 & 0.78 & 0.92 \\
\hline Ashes & 13.9 & 14.8 & 14.0 & 12.8 & 0.06 & 0.12 & 0.85 & 0.11 \\
\hline Protein & 251 & 259 & 253 & 247 & 0.56 & 0.37 & 0.90 & 0.20 \\
\hline Ether Extract & 31.0 & 26.3 & 29.6 & 35.8 & 0.45 & 0.37 & 0.86 & 0.26 \\
\hline
\end{tabular}

${ }^{1}$ Diet with CG at $100 \mathrm{~g} / \mathrm{kg}$ DM (CG +) or without crude glycerin (CG-); diet with inclusion of soybean oil at $60 \mathrm{~g} / \mathrm{kg}$ DM (Oil+) or without soybean oil inclusion (Oil-); Adjusted averages to initial body weight as a covariate.

\section{Table 5}

Effects of crude glycerin with or without soybean oil on $\mathrm{pH}$, color $\left(\mathrm{L}^{*}, \mathrm{a}^{*}\right.$ and $\left.\mathrm{b}^{*}\right)$, water holding capacity, myofibrillar fragmentation index, Warner-Bratzler shear force, thawing loss, cooking loss, total loss, and malonaldehyde of meat from young Nellore bulls in feedlot.

\begin{tabular}{|c|c|c|c|c|c|c|c|c|}
\hline & \multicolumn{4}{|c|}{ Treatments $^{1}$} & \multirow[t]{3}{*}{ SEM } & \multicolumn{3}{|c|}{$P$-value } \\
\hline & \multicolumn{2}{|l|}{$\mathrm{CG}+$} & \multicolumn{2}{|l|}{ CG - } & & \multirow[b]{2}{*}{ CG } & \multirow[b]{2}{*}{ Oil } & \multirow[b]{2}{*}{$\mathrm{CG} \times \mathrm{Oi}$} \\
\hline & Oil + & Oil - & Oil + & Oil - & & & & \\
\hline Number of observations & 7 & 7 & 7 & 7 & - & - & - & - \\
\hline $\mathrm{pH}$ & 5.75 & 5.77 & 5.70 & 5.72 & 0.19 & 0.93 & 0.75 & 0.66 \\
\hline $\mathrm{L}^{*}$ & 36.3 & 36.7 & 36.3 & 35.6 & 1.28 & 0.67 & 0.86 & 0.67 \\
\hline$a^{*}$ & 15.68 & 16.57 & 16.85 & 15.27 & 0.69 & 0.92 & 0.63 & 0.09 \\
\hline$b^{*}$ & 13.3 & 13.8 & 13.4 & 13.3 & 0.90 & 0.79 & 0.81 & 0.76 \\
\hline Water holding capacity & 78.8 & 78.9 & 78.2 & 78.7 & 0.38 & 0.36 & 0.43 & 0.56 \\
\hline Myofibrillar fragmentation index, $\mathrm{g} / 100 \mathrm{~g}$ & 60.7 & 73.8 & 62.5 & 73.2 & 7.61 & 0.93 & 0.13 & 0.87 \\
\hline Warner-Bratzler shear force, kgf & 3.79 & 4.00 & 3.53 & 3.33 & 0.46 & 0.32 & 0.99 & 0.65 \\
\hline Thawing loss, $\mathrm{g} / 100 \mathrm{~g}$ & 2.26 & 1.47 & 1.96 & 2.01 & 0.60 & 0.84 & 0.54 & 0.49 \\
\hline Cooking loss, $\mathrm{g} / 100 \mathrm{~g}$ & 17.2 & 19.2 & 18.6 & 21.3 & 1.46 & 0.25 & 0.12 & 0.82 \\
\hline Total loss, $\mathrm{g} / 100 \mathrm{~g}$ & 19.1 & 20.4 & 20.2 & 22.9 & 1.59 & 0.28 & 0.22 & 0.66 \\
\hline Malonaldehyde, $\mathrm{mg} / \mathrm{kg}$ of meat & 0.48 & 0.43 & 0.46 & 0.51 & 0.02 & 0.27 & 0.75 & 0.07 \\
\hline
\end{tabular}

Adjusted averages to initial body weight as a covariate.

1 Diet with CG at $100 \mathrm{~g} / \mathrm{kg} \mathrm{DM}(\mathrm{CG}+)$ or without crude glycerin (CG - ); diet with inclusion of soybean oil at $60 \mathrm{~g} / \mathrm{kg} \mathrm{DM}(\mathrm{Oil}+)$ or without soybean oil inclusion (Oil-).

other diets $(P<0.01$; Table 6$)$. The addition of soybean oil decreased $(P<0.01)$ by $30 \%$ the index of $\Delta^{9}$-desaturase C16 $(30 \%)$ and in $20 \%$ atherogenicity index (Table 6$)$. The addition of the crude glycerin decreased the elongase index $(P=0.04)$ in the longissimus muscle. The index of $\Delta^{9}$-desaturase C18 increased in diets without soybean oil combined with crude glycerin. There were an interaction between crude glycerin and soybean oil in the amounts of the linoleic, eicosapentaenoic, arachidonic, docosahexaenoic, total PUFA, and ratio $\mathrm{n} 6 / \mathrm{n} 3$ in meat $(P<0.05$; Table 6).

Diets with soybean oil but no crude glycerin had greater concentrations of linoleic acid and total PUFA in the muscle compared to other diets. Compared to the diets with neither crude glycerin nor soybean oil, the deposition of eicosapentaenoic and arachidonic acids was greater in diets with crude glycerin but no soybean oil and in the diets with soybean oil but no crude glycerin (Table 6).

\section{Discussion}

The intake of DM, OM, and aNDF decreased with soybean oil addition at $60 \mathrm{~g} / \mathrm{kg}$ of DM in the diet. The reduction of the DMI in the animals fed with SO diet is related with the high content of ether extract derived from the lipid supplementation, and its high proportion of UFA, which can reduce fiber digestibility and intake by filling, or by activating the chemotactic factor in the satiety center (Granja-Salcedo et al., 2017). The greater proportion of silage in the diet at $400 \mathrm{~g} / \mathrm{kg}$ DM and additionally the negative action of lipids on the fiber fraction may lower the intake by reducing fermentability and digestibility of NDF (Jenkins, 1993; Hess et al., 2008).

The fiber degradation reduction most likely occurred due to a disturbance of the membrane of cellulolytic bacteria related to a more toxic effect of UFA and PUFA in the soybean oil diets (Maia et al., 2007). The digestibility of OM also decreased when soybean oil was combined with crude glycerin, which may have occurred due to a negative effect of the activity of bacteria that metabolize non-fiber carbohydrates.

The intake of fatty acids is directly related to the intake of dry matter by the animals. Diets with oil have more UFA in their composition; consequently, the animals in these diets consumed more UFA. The decreased feed intake in diets with crude glycerin 
Table 6

Effects of crude glycerin with or without soybean oil on principal fatty (mg/100 g of meat) and index of enzymes involved on fatty acids metabolism, atherogenicity and elongase index in the muscle longissimus of young Nellore bulls in feedlot.

\begin{tabular}{|c|c|c|c|c|c|c|c|c|}
\hline \multirow{3}{*}{ Fatty acid ${ }^{2}$} & \multicolumn{4}{|c|}{ Treatments $^{1}$} & \multirow{3}{*}{ SEM } & \multirow{2}{*}{\multicolumn{3}{|c|}{$P$-value }} \\
\hline & \multicolumn{2}{|l|}{$\mathrm{CG}+$} & \multicolumn{2}{|l|}{$\mathrm{CG}-$} & & & & \\
\hline & Oil+ & Oil- & Oil + & Oil- & & CG & Oil & $\mathrm{CG} \times \mathrm{Oil}$ \\
\hline Number of observations & 7 & 7 & 7 & 7 & - & - & - & - \\
\hline \multicolumn{9}{|l|}{$S F A$} \\
\hline Myristic & 82.2 & 70.6 & 65.8 & 105 & 10.2 & 0.49 & 0.04 & 0.05 \\
\hline Pentadecylic & $12.0^{\mathrm{a}}$ & $8.40^{\mathrm{b}}$ & $8.70^{\mathrm{b}}$ & $12.3^{\mathrm{a}}$ & 0.80 & 0.06 & 0.71 & 0.01 \\
\hline Palmitic & 714 & 617 & 621 & 840 & 25.4 & 0.09 & 0.06 & 0.15 \\
\hline Margaric & 26.4 & 22.4 & 22.6 & 32.9 & 4.67 & 0.69 & 0.08 & 0.06 \\
\hline Stearic & 489 & 372 & 571 & 553 & 24.7 & 0.02 & $<0.01$ & 0.27 \\
\hline \multicolumn{9}{|l|}{ MUFA } \\
\hline Myristoleic & 18.3 & 18.1 & 12.5 & 27.3 & 3.35 & 0.44 & $<0.01$ & 0.10 \\
\hline Palmitoleic & 66.9 & 71.7 & 53.4 & 94.2 & 8.88 & 0.20 & $<0.01$ & 0.49 \\
\hline Margaroleic & 23.4 & 26.0 & 21.2 & 30.1 & 5.56 & 0.15 & 0.01 & 0.42 \\
\hline Margaroleic & 53.4 & 48.5 & 58.6 & 49.0 & 8.75 & 0.64 & 0.36 & 0.19 \\
\hline Oleic & 1050 & 961 & 1009 & 1306 & 31.2 & 0.74 & $<0.01$ & 0.85 \\
\hline Vaccenic & 71.4 & 54.6 & 74.2 & 74.9 & 8.67 & 0.63 & 0.03 & 0.98 \\
\hline \multicolumn{9}{|l|}{ PUFA } \\
\hline Linoleic & $154^{\mathrm{b}}$ & $137^{\mathrm{bc}}$ & $202^{\mathrm{a}}$ & $126^{\mathrm{c}}$ & 11.3 & 0.97 & 0.01 & $<0.01$ \\
\hline CLA & 15.9 & 9.90 & 13.6 & 11.2 & 1.13 & 0.06 & $<0.01$ & 0.96 \\
\hline$\alpha$-linolenic & 13.8 & 8.20 & 12.5 & 9.80 & 1.56 & 0.42 & $<0.01$ & 0.91 \\
\hline Eicosapentaenoic & $10.2^{\mathrm{ab}}$ & $11.0^{\mathrm{a}}$ & $12.8^{\mathrm{a}}$ & $8.40^{\mathrm{b}}$ & 2.08 & 0.38 & 0.33 & 0.01 \\
\hline Arachidonic & $43.2^{\mathrm{ab}}$ & $46.2^{\mathrm{a}}$ & $51.9^{\mathrm{a}}$ & $36.4^{\mathrm{b}}$ & 5.32 & 0.41 & 0.45 & 0.03 \\
\hline Docosahexaenoic & $14.1^{\mathrm{a}}$ & $14.8^{\mathrm{a}}$ & $15.7^{\mathrm{a}}$ & $9.50^{\mathrm{b}}$ & 2.65 & 0.14 & 0.29 & 0.02 \\
\hline Total SFA & 1391 & 1134 & 1338 & 1660 & 47.2 & 0.50 & 0.40 & 0.11 \\
\hline Total MUFA & 1341 & 1193 & 1249 & 1614 & 45.3 & 0.27 & 0.06 & 0.84 \\
\hline Total PUFA & $268^{\mathrm{b}}$ & $223^{\mathrm{b}}$ & $313^{\mathrm{a}}$ & $226^{\mathrm{b}}$ & 21.3 & 0.89 & 0.03 & 0.02 \\
\hline Total UFA & 1609 & 1416 & 1562 & 1840 & 47.8 & 0.10 & 0.96 & 0.16 \\
\hline UFA/SFA & 1.16 & 1.25 & 1.17 & 1.11 & 0.05 & 0.37 & 0.57 & 0.10 \\
\hline$n-6 / n-3$ & $11.9^{\mathrm{b}}$ & $14.0^{\mathrm{ab}}$ & $16.3^{\mathrm{a}}$ & $12.4^{\mathrm{b}}$ & 0.67 & 0.14 & 0.34 & $<0.01$ \\
\hline Index of $\Delta^{9}$ - desaturase $\mathrm{C} 16^{3}$ & 8.45 & 11.1 & 7.94 & 10.1 & 0.57 & 0.20 & $<0.01$ & 0.66 \\
\hline Index of $\Delta^{9}$ - desaturase $\mathrm{C} 18^{4}$ & 68.2 & 72.2 & 64.0 & 70.3 & 1.28 & 0.02 & $<0.01$ & 0.39 \\
\hline Elongase index ${ }^{5}$ & 66.5 & 65.8 & 70.1 & 66.6 & 1.01 & 0.04 & 0.06 & 0.18 \\
\hline Atherogenicity index ${ }^{6}$ & 0.63 & 0.69 & 0.55 & 0.72 & 0.02 & 0.40 & $<0.01$ & 0.06 \\
\hline
\end{tabular}

Adjusted averages to initial body weight as a covariate.

${ }^{\mathrm{a}-\mathrm{c}}$ Means within a row with different superscripts differ by Tukey's test at $\alpha=0.05$.

1 Diet with CG at $100 \mathrm{~g} / \mathrm{kg} \mathrm{DM}(\mathrm{CG}+$ ) or without crude glycerin (CG-); diet with inclusion of soybean oil at $60 \mathrm{~g} / \mathrm{kg}$ DM (Oil +) or without soybean oil inclusion (Oil-).

2 SFAs = saturated fatty acids; MUFAs = monounsaturated fatty acids; PUFAs = polyunsaturated fatty acids; UFAs = unsaturated fatty acids.

3 Index of $\Delta^{9}$-desaturase C16 activity $=100[(16: 1$ cis-9) $/(16: 1$ cis-9 $+16: 0)]$.

4 Index of $\Delta^{9}$-desaturase C18 activity $=100[(18: 1$ cis-9) $/(18: 1$ cis-9 $+18: 0)]$.

5 Elongase $=100[(\mathrm{C} 18: 0+\mathrm{C} 18: 1$ cis-9)/(C16:0 + C16:1 cis-9 + C18:0 + C18:1 cis-9) $]$.

6 Atherogenicity index $=[\mathrm{C} 12: 0+4(14: 0)+\mathrm{C} 16: 0] /(\Sigma$ SFA $+\Sigma$ PUFA $)$.

may be attributable to the effect of crude glycerin on palatability and viscosity, as crude glycerin can present impurities, such as methanol (Ezequiel et al., 2015). However, Mach et al. (2009) evaluated crude glycerin (85.7\% glycerol, 5.5\% salts, and 0.09\% methanol) at $100 \mathrm{~g} / \mathrm{kg}$ of ration DM of beef cattle and did not find a detrimental effect on intake and performance. The decreased DM intake in soybean oil diets did not alter the average daily gain, possibly due to an increase in the feed efficiency. However, it resulted in the reduction of carcass yield, which can be related to accretion of non-carcass components, such as liver and internal fats.

The mean value of subcutaneous fat thickness was $6.44 \mathrm{~mm}$ and met the requirements of the Brazilian beef industry, which considers the range of 3-6 mm preferable and considers fat thickness greater than $10 \mathrm{~mm}$ to be excessive. Excess fat could result in lower utilization or yield of the edible portion of meat (KUSS et al., 2005). The subcutaneous fat thickness prevents cold shortening, which directly affects the cooling rate and the conversion of muscle into meat (Zuin et al., 2012).

The WBSF was not affected by diets and the average value of 3.66 across our treatments represents an overall consumer's perception of satisfactory tenderness (Platter et al., 2003). Studies with animals receiving high concentrate diets have shown no effect on tenderness (Lage et al., 2014). The $\mathrm{pH}$ values observed in the current study are within the normal $\mathrm{pH}$ range for beef (5.4-5.8; Mach et al., 2008). The final $\mathrm{pH}$ is dependent on the lactic acid accumulation resulting from adenosine triphosphate production by using glycogen as a source of glucose (Oliveira et al., 2011). In general, cattle fed grain-based diets have greater availability of glycogen at slaughter and lower ultimate $\mathrm{pH}$ of meat (Neath et al., 2007). The final $\mathrm{pH}$ values suggest that there was no pre-slaughter stress since 
muscle acidification has occurred as expected, and that final $\mathrm{pH}$ was not altered by the lipid sources evaluated. According to Fernandes et al. (2008) the beef industry in Brazil only exports meat with pH values lower than 5.8 evaluated $24 \mathrm{~h}$ postmortem directly on the longissimus muscle. The lack of effects of diets on beef color is consistent with the lack of differences between $\mathrm{pH}$ values in our experiment.

The deposition of fatty acids in the longissimus muscle was directly related to diet composition and consumption of fatty acids. In our experiment, the intake of diets with soybean oil increased the content of stearic, linoleic, and $\alpha$-linolenic acids in the meat. These results corroborate with Granja-Salcedo et al. (2017) who claim that association of crude glycerin and soybean oil reduce the biohydrogenation of MUFA, PUFA and total UFA, and increase the duodenal flow of these acids without influencing the population of ruminal cellulolytic bacteria. Consequently altering the deposition of fatty acids in the tissues. On the other hand, the intake of diets without soybean oil increased the deposition of palmitoleic acid in the meat. Diets with soybean oil increased the amount of CLA in the longissimus muscle by $40 \%$. The total CLA content of specific foods may vary widely (Dhiman et al., 2005); for example, it varies from 0.17 to $1.35 \%$ in beef (Dhiman et al., 2005). Although the minimum effective intake of CLA for disease prevention and overall health in humans is unknown, beef provides more than $30 \%$ of its current intake (Scollan et al., 2014). This is a very important strategy to improve meat quality of the beef cattle.

Diets containing neither oil nor crude glycerin decreased deposition of eicosapentaenoic acid (EPA), arachidonic acid (AA), and docosahexaenoic (DHA) acid. This is a highly notable effect because recent studies have clearly shown the importance of polyunsaturated fatty acids and their nutritional value for human health (Abedi and Sahari, 2014). The use of vegetable oils or whole grains results in a limited increase in DHA in muscle tissue. Fish oil or fishmeal is apparently the only source that stimulates deposition of both eicosapentaenoic acid and DHA to a high extent (Raes et al., 2004).

An increase in the n-6:n-3 ratio is undesirable from a human health perspective. Despite it being important group fatty acids, high levels of n-6 are responsible for triggering a number of physiological dysfunctions, such as formation of thrombi, atheromas, and immunological disorders (Haug et al., 2007). According to the nutritional recommendations published by the World Health Organization (2003), the n-6:n-3 ratio should be between 4:1 and 5:1 in a daily diet. It is therefore important to decrease this ratio in the foods comprising substantial portions of our diet. The diet containing both soybean oil and crude glycerin showed potential in decreasing the $\mathrm{n} 6: \mathrm{n} 3$ ratio.

The desaturase (C16 and C18) index observed in the present study indicated that enzymatic activity was affected by addition of soybean oil. Diets without soybean oil increased enzyme action, which may explain the higher deposition of palmitoleic and oleic acid in the longissimus muscle of animals fed diets without soybean oil. The addition of soybean oil could serve as an alternative method of decreasing the atherogenicity index. This is an important trait as it is related to pro- and anti-atherogenic acids and indicates the potential stimuli to platelets aggregation. Therefore, the amount of anti-atherogenic fatty acids in the longissimus muscle is increased by the enhancement of the atherogenicity index. Consequently, there may be a greater potential to prevent the occurrence of coronary artery diseases by manipulating the diet of these animals (Ulbricht and Southgate, 1991).

\section{Conclusion}

The addition of crude glycerin combined with soybean oil to the diets of Nellore bulls did not effectively increase deposition of unsaturated fatty acids in meat. However, the addition of soybean oil at $60 \mathrm{~g} / \mathrm{kg}$ DM optimized feed efficiency and did not alter average daily gain besides to increase the amounts of $\alpha$-linolenic, CLA, and total MUFA in the meat.

\section{Conflict of interest}

The authors declare no conflict of interest.

\section{Acknowledgments}

The authors thank the São Paulo Research Foundation (FAPESP, grants \#2011/00060-8; \#2013/02418-2; \#2013/23959-1; \#2014/09033-1; \#2016/08585-6) for providing financial support.

\section{References}

Abedi, E., Sahari, M.A., 2014. Long-chain polyunsaturated fatty acid sources and evaluation of their nutritional and functional properties. Food Sci. Nutr. 2, 443-463. AMSA, 1995. American Meat Science Association. Research Guidelines for Cookery, Sensory Evaluation and Tenderness Measurements of Fresh Meat. National Livestock and Meat Board, IL, Chicago.

Association of Official Analytical Chemists, 1990. Official Methods of Analysis, 15th ed. AOAC, Arlington, VA.

Bayat, A.R., Tapio, I., Vilkki, J., Shingfield, K.J., Leskinen, H., 2018. Plant oil supplements reduce methane emissions and improve milk fatty acid composition in dairy cows fed grass silage-based diets without affecting milk yield. J. Dairy Sci. 101, 1136-1151.

Bligh, E.G., Dyer, W.J., 1959. A rapid method of total lipid extraction and purification. Can. J. Biochem. Physiol. 37, 911-917.

Briggs, M.A., Petersen, K.S., Kris-Etherton, P.M., 2017. Saturated fatty acids and cardiovascular disease: replacements for saturated fat to reduce cardiovascular risk. Healthcare (Basel). 5, E29.

Cochran, R.C., Adams, D.C., Wallace, J.D., Galyean, M.L., 1986. Predicting digestibility of different diets with internal markers: evaluation of four potential markers. J. Anim. Sci. 63, 1476-1483.

Culler, R.D., Parrish, F.C.Jr., Smith, G.C., Cross, H.R., 1978. Relationship of myofibril fragmentation index to certain chemical, physical and sensory characteristics of 
bovine longissimus muscle. J. Food Sci. 43, 1177-1180.

Dhiman, T.R., Nam, S.H., Ure, A.L., 2005. Factors affecting conjugated linoleic acid content in milk and meat. Crit. Rev. Food Sci. Nutr. 45, $463-482$.

Edwards, H.D., Anderson, R.C., Miller, R.K., Taylor, T.M., Hardin, M.D., Smith, S.B., Krueger, N.A., Nisbet, D.J., 2012. Glycerol inhibition of ruminal lipolysis in vitro, J. Dairy Sci. 95, 5176-5181.

Eugène, M., Martin, C., Mialon, M.M., Krauss, D., Renand, G., Doreau, M., 2011. Dietary linseed and starch supplementation decreases methane production of fattening bulls. Anim. Feed Sci. Technol. 166-167, 330-337.

Ezequiel, J.M., Sancanari, J.B., Machado Neto, O.R., Da Silva, Z.F., Almeida, M.T., Silva, D.A., Van Cleef, F.O., Van Cleef, E.H., 2015. Effects of high concentrations of dietary crude glycerin on dairy cow productivity and milk quality. J. Dairy Sci. 98, 8009-8017.

Fernandes, A.R.M., Sampaio, A.A.M., Henrique, W., Oliveira, E.A., Tullio, R.R., Perecin, D., 2008. Carcass and meat characteristic of cattle receiving differents diets in feedlot. Arq. Bras. Med. Vet. Zootec. 60, 139-147.

Ferreira, M.A., Valadares Filho, S.M., Marcondes, M.I., Paixão, M.L., Paulino, M.F., Valadares, R.F.D., 2009. Evaluation of markers in ruminant trials: digestibility. In Portuguese. R. Bras. Zootec. 38, 1568-1573.

Fiorentini, G., Lage, J.F., Carvalho, I.P., Messana, J.D., Canesin, R.C., Reis, R.A., Berchielli, T.T., 2015. Lipid sources with different fatty acid profile alters the fatty acid profile and quality of beef from confined Nellore steers. Asian Australas. J. Anim. Sci. 28, 976-986.

Goel, G., Arvidsson, K., Vlaeminck, B., Bruggeman, G., Deschepper, K., Fievez, V., 2009. Effects of capric acid on rumen methanogenesis and biohydrogenation of linoleic and a-linolenic acid. Animal 3, 810-816.

Gornall, A.G., Bardawill, C.J., David, M.M., 1949. Determination of serum proteins by means of the biureto reaction. J. Biol. Chem. 177, 751-766.

Granja-Salcedo, Y.T., De Souza, V.C., Dias, A.V.L., Gomez-Insuasti, A.S., Messana, J.D., Berchielli, T.T., 2017. Diet containing glycerine and soybean oil can reduce ruminal biohydrogenation in Nellore steers. Anim. Feed Sci. Technol. 225, 195-204.

Greiner, S.P., Rouse, G.H., Wilson, D.E., Cundiff, L.V., Wheeler, T.L., 2003. Accuracy of predicting weight and percentage of beef carcass retail product using ultrasound and live measurements. J. Anim. Sci. 81, 466-473.

Hales, K.E., Kraich, K.J., Bondurant, R.G., Meyer, B.E., Luebbe, M.K., Brown, M.S., Cole, N.A., MacDonald, J.C., 2013. Effects of glycerin on receiving performance and health status of beef steers and nutrient digestibility and rumen fermentation characteristics of growing steers. J. Anim. Sci. 91, 4277-4289.

Harfoot, C.G., Hazlewood, G.P., 1997. Lipid metabolism in the rumen. In: Hobson, P.N., Stewart, C.S. (Eds.), The Ruminal Microbial Ecosystem. Chapman \& Hall, London, pp. 382-426.

Haug, A., Høstmark, A.T., Harstad, O.M., 2007. Bovine milk in human nutrition - a review. Lipids Health Dis. 6, 25.

Hess, B.W., Moss, G.E., Hule, D.C., 2008. A decade of developments in the area of fat supplementation research with beef cattle and sheep. J. Anim. Sci. 86, 188-204.

ISO, 1978. Animal and vegetable fats and oils-Preparation of methyl esters of fatty acids. Method 5509, 1-6.

Jenkins, T.C., 1993. Lipid metabolism in the rumen. J. Dairy Sci. 76, 3851-3863.

Jenkins, T.C., Mcguire, M.A., 2006. Major advances in nutrition: impact on milk composition. J. Dairy Sci. 89, $1302-1310$.

Krueger, N.A., Anderson, R.C., Tedeschi, L.O., Callaway, T.R., Edrington, T.S., Nisbert, D.J., 2010. Evaluation of feeding glycerol on free-fatty acid production and fermentation kinetics of mixed ruminal microbes in vitro. Bioresour. Technol. 101, 8469-8472.

Kuss, F., Restle, J., Brondani, I.L., Filho, D.C.A., Perottoni, J., Missio, R.L., Amaral, G.A., 2005. Carcass physical composition and meat quality of cull cows of different genetic groups feedlot finished and slaughtered with distinct weights. R. Bras. Zootec. 34, 1285-1296.

Lage, J.F., Berchielli, T.T., Vito, E.S., Silva, R.A., Ribeiro, A.F., Reis, R.A., Dallantonia, E.E., Simonetti, L.R., Delevatti, L.M., Machado, M., 2014. Fatty acid profile, carcass and meat quality traits of young Nellore bulls fed crude glycerin replacing energy sources in the concentrate. Meat Sci. 96, $1158-1164$.

Lourenco, M., Ramos-Morales, E., Wallace, R.J., 2010. The role of microbes in rumen lipolysis and biohydrogenation and their manipulation. Animal 4, 1008-1023.

Mach, N., Bach, A., Velarde, A., Devant, M., 2008. Association between animal, transportation, slaughterhouse practices, and meat pH in beef. Meat Sci. 78, 232-238.

Mach, N., Bach, A., Devant, M., 2009. Effects of crude glycerin supplementation on performance and meat quality of Holstein bulls fed high-concentrate diets. J. Anim. Sci. 87, 632-638.

Maia, M.R.G., Chaudhary, L.C., Figueres, L., Wallace, R.J., 2007. Metabolism of polyunsaturated fatty acids and their toxicity to the microflora of the rumen. Anton. Leeuw. Int. J. G. 91, 303-314.

Malau-Aduli, A.E.O., Siebert, B.D., Bottema, C.D.K., Pitchford, W.S., 1997. A comparison of the fatty acid composition of tryacilglycerols in adipose tissue from Limousin and Jersey cattle. Aust. J. Agric. Res. 48, 715-722.

Neath, K.E., Del Barrio, A.N., Lapitan, R.M., Herrera, J.R.V., Cruz, L.C., Fujihara, T., Muroya, S., Chikuni, K., Hirabayashi, M., Kanai, Y., 2007. Difference in tenderness and $\mathrm{pH}$ decline between water buffalo meat and beef during postmortem aging. Meat Sci. 75, 499-505.

Oliveira, D.M., Ladeira, M.M., Chizzotti, M.L., Machato Neto, O.R., Ramos, E.M., Gonçalves, T.M., Bassi, M.S., Lanna, D.P., Ribeiro, J.S., 2011. Fatty acid profile and qualitative characteristics of meat from Zebu steers fed with different oilseeds. J. Anim. Sci. 89, 2546-2555.

Olson, D.G., Parrish, F.C.Jr., Stromer, M.H., 1976. Myofibril fragmentation and shear resistance of three bovine muscles during postmortem storage. J. Food Sci. 41, $1036-1041$.

Palmquist, D.L., Jenkins, T.C., 2003. Challenges with fats and fatty acid methods. J. Anim Sci. 81 (12), 3250-3264.

Platter, W.J., Tatum, J.D., Belk, K.E., Scanga, J.A., Smith, G.C., 2003. Effects of repetitive use of hormonal implants on beef carcass quality, tenderness, and consumer ratings of beef palatability. J. Anim. Sci. 81, 984-996.

Raes, K., De Smet, S., Demeyer, D., 2004. Effect of dietary fatty acids on incorporation of long chain polyunsaturated fatty acids and conjugated linoleic acid in lamb, beef and pork meat: a review. Anim. Feed Sci. Technol. 113, 199-221.

Scollan, N.D., Dannenberger, D., Nuernberg, K., Richardson, I., Mackintosh, S., Hocquette, J.F., Moloney, A.P., 2014. Enhancing the nutritional and health value of beef lipids and their relationship with meat quality. Meat Sci. 7, 384-394.

Sullivan, H.M., Bernard, J.K., Amos, H.E., Jenkins, T.C., 2004. Performance of lactating dairy cows fed whole cottonseed with elevated concentrations of free fatty acids in the oil. J. Dairy Sci. 87, 665-671.

Tapp III, W.N., Yancey, J.W.S., Apple, J.K., 2011. How is the instrumental color of meat measured? Meat Sci. 89, 1-5.

Tarladgis, B.G., Watts, B.M., Younathan, M.T., 1960. A distillation method for the quantitative determination of malonaldehyde in rancid foods. J. Am. Oil Chem. Soc. 37, 44-48.

Ulbricht, T.L.V., Southgate, D.A.T., 1991. Coronary heart disease: seven dietary factors. Lancet 338, 985-992.

Valadares Filho, S.C., Marcondes, M.I., Chizzotti, M.L., Paulino, P.V.R., 2010. Nutritional Requirements of Pure and Crossbred Zebu Cattle. On-line acess:. 2nd ed. Suprema Gráfica Ltda, Viçosa. http://www.brcorte.com.br.

Valente, T.N.P., Detmann, E., Queiroz, A.C., Valadares Filho, S.C., Gomes, D.I., Figueiras, J.F., 2011. Evaluation of ruminal degradation profiles of forages using bags made from different textiles. R. Bras. Zootec. 40, 2565-2573.

Van Soest, P.J., Robertson, J.B., Lewis, B.A., 1991. Methods for dietary fiber, neutral detergent fiber and nonstarch polysaccharides in relation to animal nutrition. J. Dairy. Sci. 74, 3583-3597.

World Health Organisation (WHO), 2003. Diet, Nutrition and the Prevention of Chronic Diseases. Report of the Joint WHO/FAO Expert Consultation. WHO Technical Report Series Vol, 916 Geneva.

Zuin, R.G., Buzanskas, M.E., Caetano, S.L., Venturini, G.C., Guidolin, D.G.F., Grossi, D.A., Chud, T.C.S., Paz, C.C.P., Lobo, R.B., Munari, D.P., 2012. Genetic analysis on growth and carcass traits in Nellore cattle. Meat Sci. 91, 352-357. 